\title{
Understanding Karo People's Culture in the Late 19th Century through Photographs by Kristen Feilberg
}

\author{
A Ariani ${ }^{1}$, I Santosa $^{2}$, A H Destiarmand ${ }^{3}$, A Sachari $^{4}$ \\ $\left\{37020006 @\right.$ mahasiswa.itb.ac.id $\left.{ }^{1}\right\}$ \\ Doctoral Program in Visual Art and Design, Institut Teknologi Bandung, Indonesia ${ }^{1}$, \\ Doctoral Program in Visual Art and Design, Institut Teknologi Bandung, Indonesia ${ }^{2}$, Doctoral \\ Program in Visual Art and Design, Institut Teknologi Bandung, Indonesia ${ }^{3}$, Doctoral Program \\ in Visual Art and Design, Institut Teknologi Bandung, Indonesia ${ }^{4}$
}

\begin{abstract}
As a multicultural country, each ethnic group in Indonesia has its own unique culture, including the Karo people in North Sumatra. Karo culture that continues to change following the dynamics of the socio-cultural life of its people, can be read through historical records or seen from visual documentation in the form of photography. The discussion in this study focuses on photographs containing the history of Karo culture by Kristen Feilberg which were taken at the end of the 19th century. Through these photos, events related to the history of the Karo people are recorded in several perspectives. Content analysis of the three photos by Kristen Feilberg was carried out by referring to Terry Barrett's method: description, interpretation, and evaluation. The results of the analysis show the characteristics of Karo culture such as the tradition of selfdecoration, the function of jewellery as a status symbol, weaving activities and traditional buildings filled with meaning. Historical information in the form of photos has become one of the medias to introduce the culture existed in the past to the younger generation and is important for strengthening awareness of the nation's history.
\end{abstract}

Keywords: Karo people's culture; photographs; Kristen Feilberg

\section{Introduction}

The character of a nation is revealed through its culture. Culture here is seen in the broadest sense, which includes its abstract forms in values and concepts, as well as those that are observable in the form of behaviour and objects produced and owned by the social entity that owns the culture concerned [1]. The Karo ethnicity as one part of the archipelago, has a variety of cultures with unique characteristics and becomes their cultural identity. According to Singarimbun [2], the cultural identity of the Karo people includes four aspects, namely clan (merga), language, arts, and customs. The cultural uniqueness of the Karo people has been formed since centuries ago but not all of them can be found in the historical records of the Karo tribe. Not much can be said about the pre-colonial history of the Karo. Despite the existence of an indigenous script (surat Batak), there are no chronicles written in that script. Such texts as do exist deal mainly with divination and spells written by priests (guru) on bark, 
bamboo and, more recently, on paper. The practical value of the script in everyday life is virtually nil.

Several foreign immigrants who came to Tanah Karo in order to carry out expeditions or as part of the colonial era had made special notes about the Karo people. Among them were Edwin Meyer Loeb, M. Joustra, J. H. Neumann, and William Marsden. The arrival of the Europeans not only produced important records about the Karo people at that time, but also visual recordings in the form of photographs. They use photographic technology to document the exoticism of the Tanah Karo landscape, the sociology of indigenous peoples, objects of use, architecture, and other local cultures. The images produced by photographic techniques are closer to the actual reality, so that these explorers can visually describe what they see around Karo lands.

Some of the earliest photographs of Karo villages were taken during the period of Dutch interventions in 1868-69 by photographer Kristen Feilberg (1839 - 1919). Feilberg, who had studios in Singapore and Penang, was commissioned by the Dutch East Indies administrators to photograph the Karo in the 1870's. [3]. Kristen Feilberg was born in 1839 in the Danish town of Vester Vedsted, and he travelled a lot and had an eventful life. In 1864 he worked as a photographer in Singapore with August Sachtler. From 1865 to 1867 in Penang with Hermann Sachtler and from 1867 independently in Penang. In 1867 he appeared in Deli (Melayu). It could be that he carried out his work in Deli as trips from his studio in Penang [4]. The photos that Feilberg took while in Karo lands were not much different from other photographers, recording the exoticism of the landscape and local culture. From some of the photos he produced, Feilberg tried to produce natural poses even though there are still poses of the subject (indigenous people) that are set to look 'westernized'. This paper aims to capture messages about the cultural characteristics of the Karo people at the end of the 19th century through photographic works produced by Kristen Feilberg. Through these photographic documentations, we can understand and learn about the history of Karo culture, some of which currently no longer exist.

\section{Method}

This paper will discuss three black and white photographs by Kristen Feilberg that record the daily activities of the Karo people in the 1870s. The photos are in the collection of The National Museum of World Cultures (Netherlands). Among the photographs by Kristen Feilberg during his stay in Tanah Karo, three photos were chosen to be considered as the most representative of the Karo people life inte 1870's. The photos consist of: portrait of a Karo Batak woman, chief of a Karo Batak village with his wife and daughter, and village view with Karo Batak women behind weaving machines. According to Barret [5] in his book Criticizing Photographs, there are several stages to critique a photo, consist of: description, interpretation, and evaluation. In this study, content analysis of photos using the Terry Barret method will be used with more emphasis on the description and interpretation stages. This is used in order to understand the 'content' of the photos by analysing the subject, form, media, style, comparison, and the message the photographer wants to convey [6]. 


\section{Results and Discussion}

\subsection{Photo 1: Portrait of a Karo Batak Woman}

This photo shows the figure of a young woman as the subject. As the title suggests, the woman in the photo is from the Karo ethnic group. The dark-skinned young woman wears a cloth covering her body from chest to calf and drapes a shawl over one shoulder. The interesting part is the woman's sitting position, which is lifting one leg on the wooden box she sits on with one arm resting on her knee. This position is uncommon for Eastern women, since it is usually performed by men. This woman's eyes look sharp into the camera. Some jewelleries appeared to be worn are two types of earrings, a necklace, and several rings on the index and little fingers of her left hand. This photo was taken in a studio (or it could be a home interior), which is marked with a canvas screen as the background. Judging from the dark impression on the right side of the face and other body parts, the photographer uses the light source from the left side of the subject. This can also be seen at the feet of the subject which shows the shadow clearly. One of the characteristics of Feilberg's photography is that it produces very sharp photos. In addition, another characteristic is a distance between the subject and the blurred background [6]. These characteristics can be seen in this photo, sharpness in the subject and blurring effect in the background.

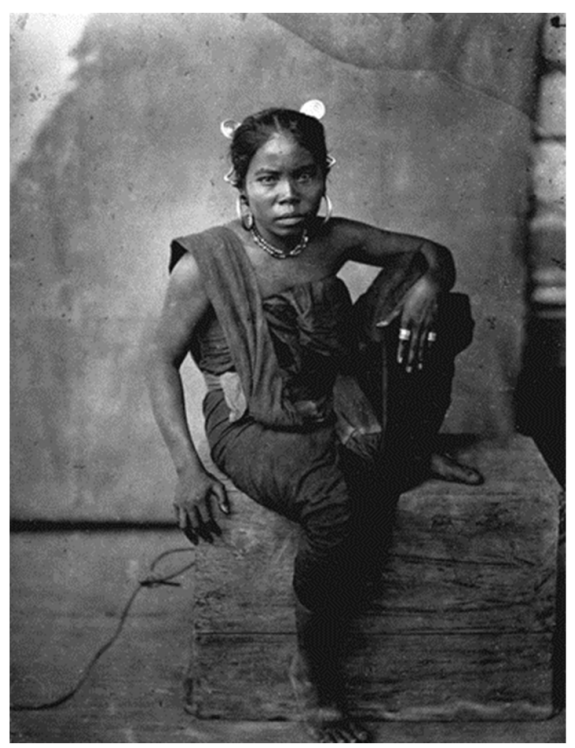

Fig. 1. Portrait of a Karo Batak woman

Earrings in the form of a spiral, called padung-padung, are worn on the upper earlobe towards the back of the head. This jewelry is made of solid silver and was worn by women of the Karo tribe in the late 19 th to early 20th centuries [7]. In the photo, padung-padung are tucked into the hair at the back. The form of this jewelry is adapted from nature, the shape of rolluyged up millipede or tangga-tangga, in Karo language [8]. Another opinion states that this shape resembles the curl shoots of ferns. This shows the Karo people's high appreciation for nature which has provided an abundant source of life. In addition to padung-padung, this 
woman also wears round earrings with a fairly large diameter. The silver beaded necklace worn by this woman is also known as Turkish beads and is quite popular in North Sumatra. Decorative ornaments are engraved on the surface of the beads while the middle part contains wood or tree resin [9].

Observing the jewelleries, especially padung-padung, this woman is thought to come from a wealthy family. Only Karo women from honorable and affluent class can wear this jewelry. But the odd thing about this photo is her sitting position. Most European photographers will arrange the subject to pose in a formal sitting position that is aristocratic and classy. Instead, the sitting position shown in the photo looks arbitrary and far from classy. In this case, it could be that the woman does not want to adjust her pose and wants to look natural as she is. It could also happen the other way around, where the photographer adjusts the pose to emphasize to the audience of his photos the characteristics of the indigenous people in Tanah Karo. However, this photo is interesting because the woman's sitting position looks contradictory to her position as an upper-class woman which is marked by the accessories she wears.

\subsection{Photo 2: Chief of a Karo Batak Village with His Wife and Daughter}

In this second photo, an adult man is seen sitting below with a woman, while a young girl is standing between them. The three of them sit and stand on top of pandanus mat. In the background, several people are seen sitting on top of a wooden building, one person is facing the camera, while several others are sitting facing their backs. A dog is seen sleeping in the gap between the wooden beams that the building was constructed from. The man in the photo wears a white long-sleeved shirt and sarong, and a cloth wrapped around his head. The two women are dressed by wearing a cloth wrapped around the chest to the ankles. The girl drapes the shawl over her shoulders and stands with her right hand resting on the wooden structure. Her eyes turn downward, towards his mother. The mother sits on her knees while holding a woven pandanus container called kampil on her lap. This container is usually used to store equipment for chewing betel nut, which consist of betel leaf (belo), areca nut (mayang), gambier (gamber), tobacco (mbako), and lime. The mother and daughter part their hair and pin it behind their heads, wearing heavy silver U-shaped earrings [10].

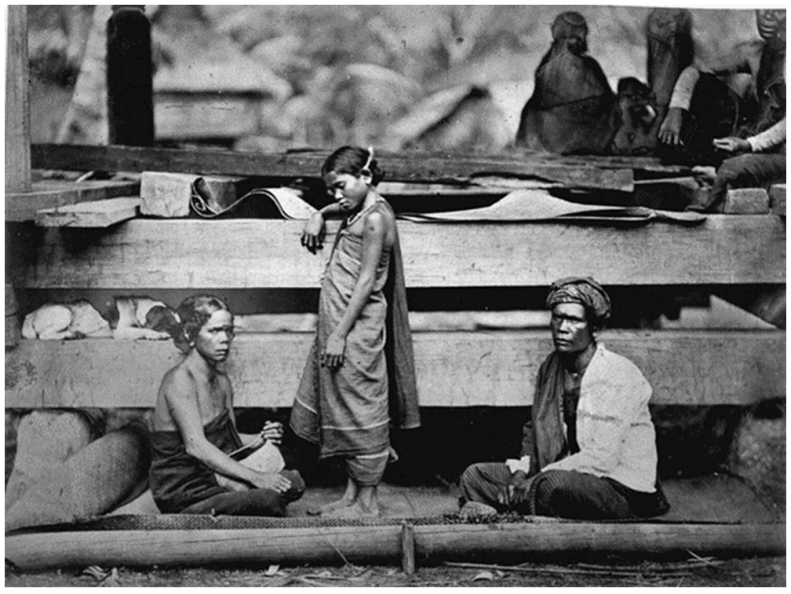

Fig. 2. Chief of Karo Batak village with his wife and daughter 
The adult male subject in the photo is a village chief. As people who have important positions in their territory, their wives and daughters wear padung-padung earrings as a status symbol. This status symbol is also attached to the female figure of Karo in previous photo. Only upper-class Karo women who represent their lineage, or those whose ancestors were the founders of the village (important people in the area), and who come from affluent groups, who wear padung-padung [11]. The photo was taken outdoors with a wooden building in the background, thought to be a place to store crops (rice) called keben or sapo. Traditional Karo buildings are made with simple technology but use quality materials. Its distinctive feature is that it does not use nails. The photo shows large and sturdy wooden blocks used as construction. Like most of Feilberg's photos, the subject of the photo looks sharp while the background is blurred. The husband and wife in the photo look at the camera without smiling. The tense and suspicious expression on their faces may have happened because they were not used to be captured in photo by strangers.

\subsection{Photo 3: Village View with Karo Batak Women Behind Weaving Machines}

While Kristen Feilberg's two previous photos focused on a subject with a blurred background, in the following photo both the subject and the background appear balanced. This photo records the activities of several Karo women with various age group, ranging from children, adults, and the elderly. These women weave cloth (uis) in their yard. Some of them are seen holding babies or cradling children, some are seen conversing. Almost all of the women in the photo are wearing a headscarf or cloth covering the head (tudung) and wrapped around the chest to the bottom. But there are some women who leave the chest exposed. Besides tudung, they also wear padung-padung jewelry. The head covering, or hood commonly worn by Karo women is called uis batu jala. This cloth is black in colour and on the right and left edges there is a white colour with a decorative motif of a goat or repeated curved lines. According to Sitepu [8], the main material for making uis is kembayat, cotton from local residents' plantations which then spun into yarn. The materials used for colouring are ash water, lime, turmeric and telep, a type of plant called sarap. The photo shows a simple loom, called a pemapan, made of bamboo and wood, which serve as a place for hanging threads and separating the top and bottom threads.

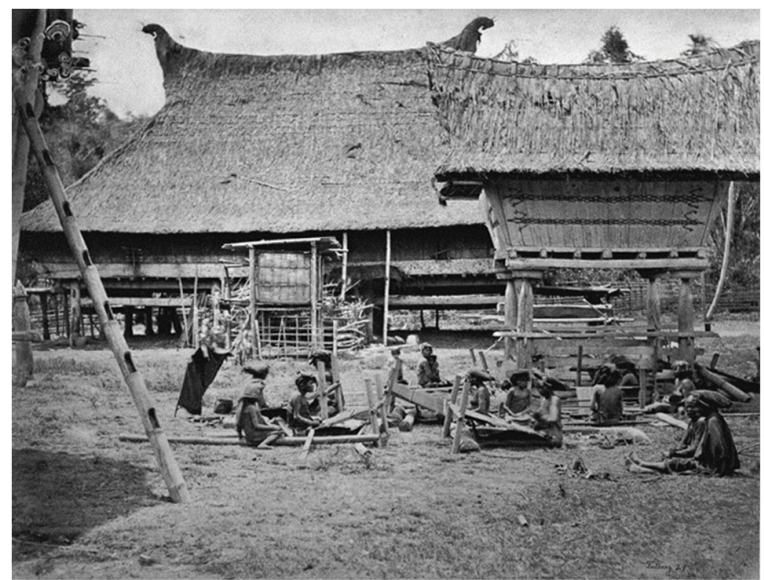

Fig. 3. Village view with Karo Batak women behind weaving machines 
In the background, there is Karo traditional house building with thatched roof, wooden walls, and in the form of a stilt house. Traditional buildings like this are often found in villages such as Lingga, Dokan, Sikap and Parimbun villages in the Barus Jahe sub-district. This traditional house is usually inhabited by eight families, so it is called siwaluh jabu. On the roof there are a pair of male buffalo heads placed on the platform (tersek) facing upstream of the river, and female buffalo heads facing downstream. Karo people view buffalo as a symbol of fertility and honour. All traditional Batak Karo buildings place a buffalo head as a symbol of honour and authority. The smaller buildings as mentioned in the second photo are called keben or sapo. On the wall (derpih), there is a decorative (gerga) pengretret or pengaretret that resembles a two-headed lizard as a symbol of the God of Prosperity. In this photo, Feilberg takes a picture with a natural pose. This can be seen from some of the women whose body parts look blurry, indicating that when the picture was taken, they were moving. Overall, this photo can represent the life of the Karo people in the 1870s, especially the women activities. Although the tradition of weaving uis in Tanah Karo is not as popular as ulos, until now uis Karo are still used in traditional events.

\section{Conclusion}

The photographs by Kristen Feilberg discussed above visualize the cultural characteristics of the Karo people at the end of the 19th century, specifically in the 1870s. Feilberg's photographic technique has produced beautiful photographic works and has become an important documentation in the history of the Karo people. Although the technology used was still simple, the quality of the resulting photo is able to capture the subject and other artifacts in a sharp and detailed manner. These photos are able to convey messages about the characteristics of Karo culture such as the tradition of self-decoration, the function of padungpadung jewelry as a status symbol, uis weaving activities, and traditional buildings that are full of meaning. Through this paper, it can be seen that photography plays an important role in disseminating the history and culture of a society through a holistic context. By practicing sensitivity in understanding a photo, our understanding of the historical value of the past recorded in the photo will also strengthen our awareness of the importance of the history of a nation.

\section{Acknowledgment}

Financial support for this study was provided by a grant from the Faculty of Art and Design, Universitas Trisakti, Jakarta, Indonesia. The first author would like to thank Dr. Sangayu Ketut Laksemi, M. Ds as the dean who have motivated and facilitated the first author's doctoral studies. Thank are also due to Dr. Imam Santosa, M. Sn, Dr. Achmad Haldani Destiarmand, M. Sn, and Dr. Agus Sachari, M. Sn, for their suggestions on preparing the manuscript.

\section{References}

[1] E. Sedyawati, Kebudayaan di nusantara. Dari keris, tor-tor, sampai industri budaya. Depok: Komunitas Bambu, 2014. 
[2] M. Singarimbun, Kinship, descent, and alliance among the Karo Batak. California: University of California Press, 1975.

[3] A. Groenveld, "Toekang Potret: 100 jaar fotografie in Nederlands Indië 1839-1939, (Photographer/Portrait-Maker: 100 Years of photography in the Dutch East Indies, 1839-1939)," in Published to accompany the exhibition in the Museum of Ethnology, Rotterdam, March 4 - M, Den Haag: CIP-gegevens Koninklijke Bibliotheek, 1989.

[4] J. Falconer, A vision of the past, a history of early photography in Singapore and Malaya, the photographs of G.R. Lambert \& Co. Singapore, 1987.

[5] T. Barrett, Criticizing photographs: An introduction to understanding images, 3rd ed. New York: Mc Graw Hill, 2006.

[6] W. Lokman, I. Zahar and A. Datoem. 2018. Foto hitam putih masyarakat Melayu abad ke-19 karya Gustav Richard Lambert. Wacana Seni Journal of Arts Discourse 17: 77106. https://doi.org/10.21315/ws2018.17.3.

[7] A. Sibeth, The batak: Peoples of the island of sumatra (Living with ancestors). United Kingdom: Thames \& Hudson, 1991.

[8] A. G. Sitepu, "Mengenal seni kerajinan tradisional Karo," Medan: E Karya, 1980.

[9] B. W., Ethnic jewellery from indonesia; Continuity and evolution. Singapore: Editions Didier Millet, 2011.

[10] E. M. Loeb, Sumatra: sejarah dan masyarakatnya. Yogyakarta: Penerbit Ombak, 2011.

[11] A. Richter and B. W. Carpenter, Gold jewellery of the the indonesian archipelago. Singapore: Editions Didier Millet, 2011. 